\title{
Fatal heart block due to mesothelioma of the atrioventricular node
}

\author{
D W EVANS, * P G I STOVIN $\dagger$ \\ From the ${ }^{\star}$ Regional Cardiac Unit and $\dagger$ Department of Pathology, Papworth Hospital, Cambridge
}

SUMMARY A fit young man of 23 was symptom free until the time of his death despite a narrow complex complete heart block, with resting heart rates down to 35 beats $/ \mathrm{min}$, that was first diagnosed when he was 10 . The clinical diagnosis remained congenital heart block. Necropsy showed extensive infiltration of the atrioventricular node and proximal bundle by mesothelioma tissue. Pacing had not been advised because of his excellent exercise tolerance.

When not associated with other congenital cardiac abnormalities, complete heart block diagnosed early in life is compatible with a responsive cardiac output and long term survival. ${ }^{12}$ The individual patient's prognosis cannot be known with certainty ${ }^{3}$ and symptoms such as syncope or impaired effort tolerance are the usual indications for pacing, ${ }^{4}$ there being an increased incidence of these symptoms after the age of 30 years. $^{56}$

McHenry noted a progressive decrease in resting heart rate as these patients grow older, ${ }^{7}$ persistent resting rates of 50 beats per minute or less being associated with syncope in children and young adults. ${ }^{8}$ The subject of this report had resting bradycardia of that order but remained symptom free with a better than average working capacity right up to the time of his unexpected death.

\section{Case report}

Complete heart block with narrow QRS complexes and a resting bradycardia of 41 beats per minute was first reported when he was 10 years old. His parents were alive and well. Clinical accompaniments were cannon waves, a forceful apex beat, and a pulmonary ejection murmur of moderate intensity. Antisteptolysin O, toxoplasma, and viral titres were normal. He was referred for cardiological assessment at the age of 15 years because associated hypertrophic cardiomyopathy was suspected. $M$ mode echocardiography showed no asymmetry. The left ventricular free wall was $20 \mathrm{~mm}$ thick and the septum was $18 \mathrm{~mm}$, with normal chamber dimensions and

Requests for reprints to Dr D W Evans, Regional Cardiac Unit, Papworth Hospital, Cambridge CB3 8RE.
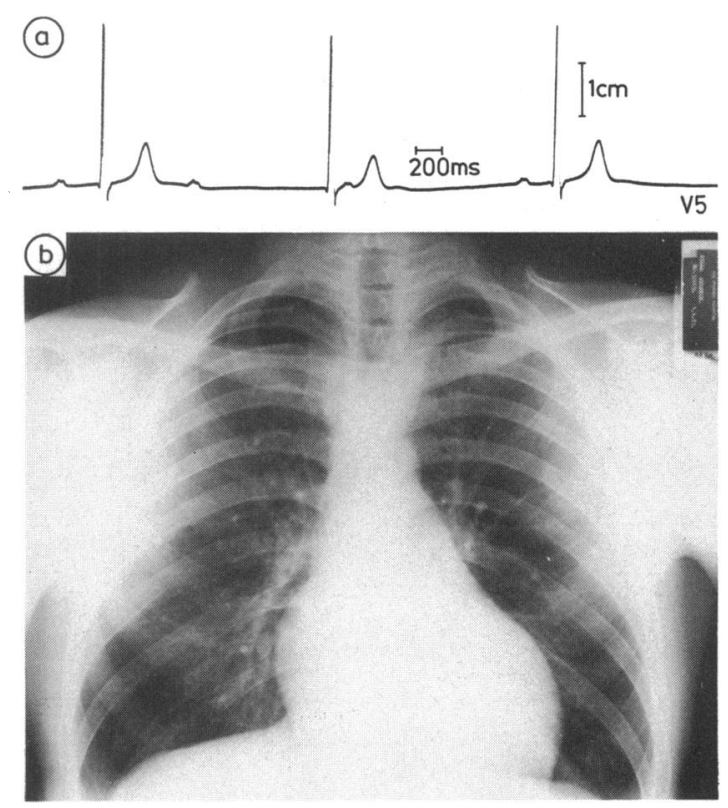

Fig 1 (a) Electrocardiogram recorded at age 20 years. (b) Chest $x$ ray at 23 years.

valve appearances. At that time his right brachial blood pressure was $110 / 55 \mathrm{~mm} \mathrm{Hg}$ and his heart rate was 42 beats per minute at rest, readily increasing to 64 beats per minute (without extrasystoles) on light exercise. He was accustomed to strenuous exercise including football and wrestling.

An electrocardiogram (fig 1) recorded in 1982, when he was 20 years old, confirmed complete heart block with narrow QRS complexes, the atrial rate 


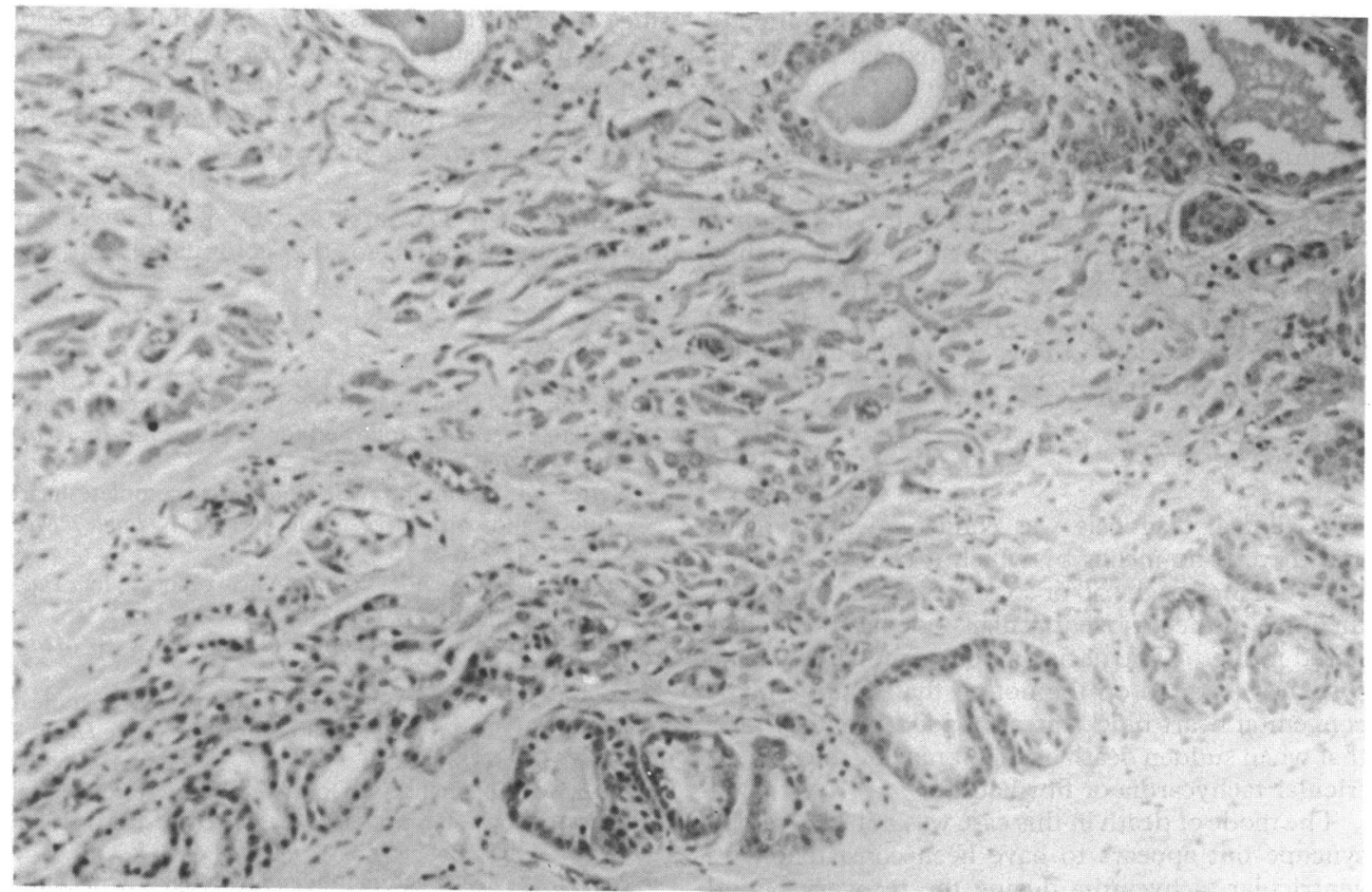

Fig 2 Photomicrograph of part of the atrioventricular node which is permeated and surrounded by mesothelioma tubules and cysts. A fibrous atrioventricular ring is present (bottom right). Haematoxylin and eosin.

showing considerable variation with constancy of the ventricular rate at 35 beats per minute. QTc was $350 \mathrm{~ms}$. The $\mathrm{S}$ waves in V2 measured $30 \mathrm{~mm}$. Chest $x$ ray showed a bulky cardiac outline with a normal transverse cardiac diameter $(140 \mathrm{~mm})$.

He remained very fit, working as a farm labourer, and reported no dizziness or effort related symptoms at the time of his last review in April 1985. He was then aged 23 years (height $1.85 \mathrm{~m}$ and weight $79.5 \mathrm{~kg}$ ). His resting heart rate was 40 beats per minute and systolic blood pressure $90 \mathrm{~mm} \mathrm{Hg}$. The transverse cardiac diameter on $x$ ray (fig 1 ) was $168 \mathrm{~mm}$.

In May 1985 he loaded a lorry with bales of straw and set off in it, chatting happily. Three or four minutes later he complained of central chest pain, writhed "for a few moments", and died. He had not appeared to be dyspnoeic.

\section{PATHOLOGICAL EXAMINATION}

At necropsy the only gross abnormalities were pulmonary oedema, pericardial adhesions, and an apparently enlarged heart. The heart weight $(560 \mathrm{~g})$ was substantially in excess of the upper figure $(372 \mathrm{~g})$ for a $79 \mathrm{~kg}$ man cited by Ludwig $(1979)^{9}$ and the limit of $399 \mathrm{~g}$ for a $1.90 \mathrm{~m}$ man given by Olsen
$(1980)^{10}$; though Hangartner et al (1985) give an upper $95 \%$ confidence interval of $584 \mathrm{~g}$ for a normal $80 \mathrm{~kg}$ man. ${ }^{11}$ The adhesions were confined to the region of the mid-anterior interventricular groove, the underlying vessels and myocardium being normal. The posterior interatrial septum was slightly thickened by pale soft tissue. The right ventricle and valves were normal. On the left side the atrium, mitral, and aortic valves were normal. The left ventricle was hypertrophied with the thickness of the free wall varying from 18 to $20 \mathrm{~mm}$. The septum was $18 \mathrm{~mm}$ thick with mild milky white thickening of the endocardium over the flat basal region.

The atrioventricular node, bundle of $\mathrm{His,}$ and proximal bundle branches were dissected out en bloc and serially sliced every $2-3 \mathrm{~mm}$. These eight blocks were each cut on their inferior (posterior) faces. Eighteen further blocks were examined, three from the atria, two from the interventricular septum, five from the left ventricular free wall, five from the free wall of the right ventricle, and three that combined myocardium and descending coronary arteries. Electron microscopy was not undertaken because of the interval between death and necropsy and the fact that the heart had been fixed in formol saline before receipt by PGIS. 
Microscopically there was extensive infiltration of the atrioventricular node and proximal bundle by gland-like mesothelioma tissue (fig 2). This infiltrate was also separating the node from the atrial myocardium. The endocardium of both ventricles was slightly thickened and contained strands of smooth muscle, indicating some degree of longstanding dilatation. The left ventricular muscle was slightly hypertrophied with myocytes up to $25 \mu \mathrm{g}$ diameter and there was no myocyte disarray. As well as old epicardial adhesions there was some epicardial lymphocytic infiltrate.

\section{Discussion}

The clinical diagnosis was congenital heart block and there is no means by which it could have been refined. None of the 50 or so reported cases of mesothelioma of the atrioventricular node has been diagnosed in life. ${ }^{12}$ The decision not to implant a pacing system was based on the notion that asymptomatic congenital heart block carries a good prognosis and that when sudden death occurs it may be due to ventricular tachycardia or fibrillation. ${ }^{12}$

The mode of death in this case was not unheralded syncope but appears to have been consistent with ventricular tachycardia during the recovery period after stenuous exertion-a possibility indicated by Cobbe. ${ }^{4}$ It may be that formal exercise testing would have shown a tendency to ventricular extrasystoles ${ }^{7813}$ and it is possible that pacing with a dual chamber or other rate-responsive system would have reduced or abolished it. It may also be that pacing should have been offered because of the clinical, electrocardiographic, radiographic, and echocardiographic indications of left ventricular hypertrophy. In the absence of cardiomyopathy, it is possible that such a system would, over the years, have limited cardiac hypertrophy to a degree that was compatible with the patient's demands for a high cardiac output on exercise and would have afforded some protection against myocardial instability caused by bradycardic underperfusion during the post-exertional phase.

It is most unlikely that the recurrent mild pericarditis played any part in this man's death. None of the multiple sections of the area of the mesothelioma showed any acute event such as a haemorrhage or rupture of a cyst that might have triggered a ventricular tachycardia.

The mesothelioma or adenomatoid tumour of the heart has been recognised as a cause of heart block since the report of Armstrong and Monckeberg in 1911. ${ }^{14}$ McAllister has described it as the smallest tumour capable of causing sudden death, ${ }^{15}$ though the time course from its origin (before birth) to death may extend over many years.

We thank Dr T D Marsh and Dr J E Trowell for information essential to the compilation of this report.

\section{References}

1 Campbell M, Emanuel R. Six cases of congenital complete heart block followed for 34-40 years. Br Heart f 1967;29:577-87.

2 Vetter VL, Rashkind WJ. Congenital complete heart block and connective-tissue disease. $N \mathrm{Engl} \mathcal{F} \mathrm{Med}$ 1983;309:236-8.

3 Esscher E. Congenital complete heart block. Acta Paediatr Scand 1981;70:131-6.

4 Cobbe SM. Congenital complete heart block. $\mathrm{Br} \mathrm{Med} \mathcal{F}$ 1983;286:1769-70.

5 Esscher EB. Congenital complete heart block in adolescence and adult life. A follow-up study. Eur Heart $\mathcal{I}$ 1981;2:281-8.

6 Reid JM, Coleman EN, Doig W. Complete congenital heart block. Report of 35 cases. Br Heart $\mathcal{f} 1982$; 48:236-9.

$7 \mathrm{McHenry}$ MM. Factors influencing longevity in adults with congenital complete heart block. Am $\mathcal{f}$ Cardiol 1972;29:416-21.

8 Karparwick PP, Gillette PC, Garson A Jr, et al. Congenital complete atrioventricular block: clinical and electrophysiologic predictors of need for pacemaker insertion. Am f Cardiol 1981;48:1098-102.

9 Ludwig J. Current methods of autopsy practice. 2nd ed. Philadelphia, London, Toronto: WB Saunders, 1979:670.

10 Olsen EGJ. The pathology of the heart. 2nd ed. London: MacMillan Press, 1980:14.

11 Hangartner JRW, Marley NJ, Whitehead A, Thomas AC, Davies MJ. The assessment of cardiac hypertrophy at autopsy. Histopathology 1985;9:1295-306.

12 Nishida K, Kamijima G, Nagayama T. Mesothelioma of the atrioventricular node. $B r$ Heart $\mathcal{F}$ 1985; 53:468-70.

13 Winkler RB, Freed MD, Nadas AS. Exercise-induced ventricular ectopy in children and young adults with complete heart block. Am Heart f 1980;99:87-92.

14 Armstrong $\mathrm{H}$, Monckeberg JG. Herzblock bedingt durch primaren Herztumour bei einem 5 jahringen Kinde. Deutsches Archiv für klinische Medizin 1911;102:144-66.

15 McAllister HA. Tumours of the heart and pericardium. In: Silver MD, ed. Cardiovascular pathology. New York, Edinburgh, London, Melbourne: Churchill Livingstone, 1983:930-2. 